\title{
Collaborative Governance in the Development of Lusi Island Tourism Sidoarjo District in the New Normal Era
}

\author{
Isnaini Rodiyah ${ }^{1}$, Hendra Sukmana ${ }^{2}$, Monicha Puspitasari ${ }^{3}$ \\ Universitas Muhammadiyah Sidoarjo, Jalan Mojopahit Nomor 666B, Sidoarjo \\ Iisnainirodiyah@umsida.ac.id \\ ${ }^{2}$ hendra.sukmana@umsida.ac.id \\ ${ }^{3}$ monicapus16@gmail.com
}

\begin{abstract}
The research purposes were to analyze 1) The impact of the Covid-19 pandemic in the development of Lusi Island tourism; 2) Collaborative governance in developing Lusi Island tourism in Sidoarjo during the new normal period. qualitative descriptive research, data collection techniques: interviews, observation, and documentation. Data analysis techniques: data collection, data reduction, data presentation, and drawing conclusions.Research results: The COVID-19 pandemic has a significant impact on the economy and health of the people around Lusi Island tourism. Meanwhile, the collaborative governance of Lusi Island tourism development is not optimal, this can be seen in the initial conditions, there are differences in strength and authority. Facilitative leadership is not carried out by the government. The institutional design does not yet have a legal basis and an MOU that regulates the legitimacy of actors. The collaborative process is not optimal, the meetings are held online. The result of the collaboration is the absence of involvement between the Government, the private sector and academics. The outcome achieved was limited to the spirit of POKDARWIS and APPWS in developing Lusi Island tourism.
\end{abstract}

Keywords: Collaborative Governance, Stakeholder, Lusi Island Tourism, New Normal Era.

\section{INTRODUCTION}

Tourism is one of the leading sectors in the implementation of national and regional development. In the last decade, tourism has become the most promising sector for income. The tourism sector also absorbs a lot of labor.

Sidoarjo is one of the areas that has the opportunity to become a leading tourist destination because of its geographical conditions which are located between two major cities, they are Surabaya and Malang. One of the potential tourist attractions in Sidoarjo is Lusi Island.

Lusi Island is located in Kedungpandan Village, Jabon District, Sidoarjo. Lusi Island is included in the type of marine tourism because to arrive at this tourist attraction, visitors must cross the Porong River. Lusi Island Tourism has been operating since 2017 after being inaugurated and named by the Minister of Maritime Affairs and Fisheries Susi Pudjiastuti. The name Lusi Island stands for Lumpur Sidoarjo (Sidoarjo Mud).

Kedungpandan Village has the potential for rice fields and fish ponds that are being considered. Even the area of Kedungpandan Village is dominated by 1,176 hectares of fish pond land. Most of the potential human resources in Kedungpandan Village are work as fisherman and farmers as described in the table below: 
Table 1. Population by Occupation

\begin{tabular}{|l|l|c|}
\hline No. & \multicolumn{1}{|c|}{ Type of Work } & Number in Person \\
\hline 1. & Civil Servants & 38 \\
\hline 2. & Police/Army & 9 \\
\hline 3. & Fisherman & 25 \\
\hline 4. & Private Labour & 290 \\
\hline 5. & Traders/Seller & 175 \\
\hline 6. & Construction Business & 70 \\
\hline 7. & Industrial/Handicraft & 12 \\
\hline 8. & Business & 6 \\
\hline 9. & Transportation Business & 324 \\
\hline 10. & Farmers & 640 \\
\hline 11. & Farm Workers & 115 \\
\hline & $\quad$ Total & 1.704 \\
\hline
\end{tabular}

Source: Kedungpandan Village Government (2019)

Seeing the condition of the residents of Kedungpandan Village, the majority of whom work as farmers and laborers, it is necessary to empower tourism development that has the potential to become an attraction at the local, regional, national and international levels.The Tourism Awareness Group (Pokdarwis) and the Association of Sidoarjo Travel Companies (APPWS) see a promising opportunity on Lusi Island as a tourist destination worthy of being visited by domestic and foreign tourists. Lusi Island tourism has its own uniqueness, because the process of its formation comes from silt, which is the only one in the world[8]. Even in 2018, Lusi Island received the Anugerah Pesona Indonesia Award as the most popular ecotourism.Information about the beauty of Lusi Island tourism has made the number of tourist visits increase in recent years. The following are the number of tourist visits on Lusi Island during 2017-2018.

Table 2. Number of Tourist Visits on Lusi Island in 2017-2018

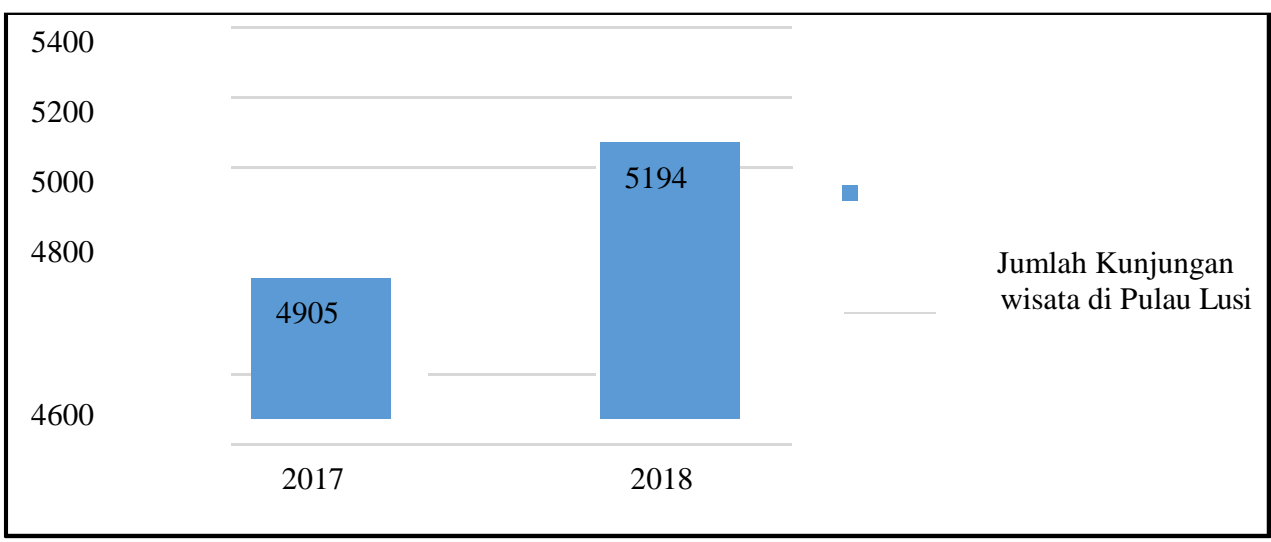

Source: (Dinas Kepemudaan Olahraga dan Pariwisata Kabupaten, 2019)[4] 
The increase in the number of tourist visits, the opportunity for Lusi Island tourism to become a tourist destination, which deserves to be developed, not only presenting the charm of the mangrove forests and wanamina ponds around Lusi Island [5]. This phenomenon has a positive impact on the residents of Kedungpandan Village. Every day an average of 300600 visits, so that the stalls owned by residents around the pier are also getting crowded because of the many tourists to enjoy culinary delights. This condition has an impact on increasing the income of the residents in Kedungpandan Village.

The situation has changed significantly since the Covid-19 Pandemic which affected the tourism sector around the world, including Lusi Island. Residents of Kedungpandan Village have been relying on the economy from tourism on Lusi Island to earn income. Residents who previously worked mostly as fisherman have switched to become entrance guards, security guards, cleaners, and owners of stalls around Lusi Island tourism. Since the pandemic spread, people have almost no income.

Facing the New Normal era, special preparation and guidelines from the government are needed to revive Lusi Island tourism and the community's economy. The community hopes that the government will immediately develop tourism and reopen Lusi Island tourism in order to earn income in the New Normal Period. However, so far there has been no response from the government, either at the village or regional levels. [7] in research conducted in Nganjuk, states that tourist objects in rural areas are less attractive because of poor service. Low support from the Regional Tourism Office has resulted in less optimal tourism development. In addition, there is a need for a strategy and concentration for the development of tourist objects. Research related to collaboration was carried out by [15], that collaboration in the implementation of development, government actors are the main support, while community involvement is still limited.

In contrast to the results of the research above, the tourism development found in Lusi Island is an initiative that comes from local residents who are members of POKDARWIS (Tourism Awareness Group) as well as support from APPWS (the Association of Sidoarjo Travel Companies), these two groups are trying to revive and marketing the tourism potential of Lusi Island[9], to show significant results. This condition shows that awareness and willingness grow from the bottom-line which has the capacity and enthusiasm to empower the economy of rural communities. Because it is the private sector and the community who initiate tourism development. Ironically, the Sidoarjo Regional Government cannot immediately take action to revive Lusi Island tourism in the New Normal era, because so far there has been no clear boundary of authority between the central government and regional governments in tourism development.

Based on the background above, the researcher conducted research entitled "The Development of Lusi Island Tourism Sidoarjo District In The New Normal Era Using Collaborative Governance Approach". The purpose of this study is to analyze and describe the tourism development of Lusi Island, Sidoarjo District in the new normal era using a collaborative governance approach.

\section{METHODS}

This research uses descriptive research with a qualitative approach. Qualitative research is research that is useful for examining the condition of natural objects [14]. The location in the study, in Kedungpandan Village, Jabon District, Sidoarjo, and the research site is in the Kedungpandan Village Office, Jabon District, Sidoarjo. The legal basis for this research is the Law of the Republic of Indonesia Number 10 of 2009 concerning Tourism [12].Data collection techniques are carried out through interviews, observation, and documentation. The technique of determining informants was done by purposive sampling. Technique of analyzing data uses intriguing techniques[10] namely data collection, data reduction, data presentation, and drawing conclusions.

\section{RESULTS AND DISCUSSION}

\subsection{Impact of the Covid-19 Pandemic on the Socio- Economic Conditions of Lusi Island Tourism}

The covid-19 pandemic has a significant impact on the residents of Kedungpandan Village. Residents activities in the economic sector are paralyzed due to the closure of Lusi Island tourism. Lusi Island tourism officers switch professions to become fishermen. However, the fish caught were not selling well, as a result of the limited opening hours of the market in accordance with the PSBB policy.

The impact of the pandemic was also felt by other tourism officers such as security, cleanliness, entrance guards, before the Covid-19 pandemic they received sufficient salaries from tourism activities. monthly income can reach 3 million, but since the pandemic, they have lost their jobs and confused about how to generate income, as well as stall owners around tourist attractions who also complain about lack of buyers.

In terms of health, there are residents of Kedungpandan village exposed to Covid-19, at 
least 8 people were exposed to Covid-19, with details of 4 people being monitored (ODP) and 4 others being Patients Under Monitoring (PDP) [6].

Meanwhile, the conditions of the Lusi Island tourism infrastructure facilities and at the Tlocor pier both before and after the pandemic were also increasingly poorly maintained and inadequate as tourist destinations, such as bathrooms, waiting rooms, rescue posts, and clean water. Thus, when there is a word and a plan to reopen Lusi Island tourism in the new normal era, supporting equipment is needed to get used to a clean and healthy lifestyle while maintaining physical distancing according to health protocols. Of course, funding must also be considered by all parties, because so far, funding activities have only been sourced from community organizations and assistance from Bumdes. Even the village government is also not interested in making the tourism sector a leading source of income to increase Village Original Income.The conditions that exist in Lusi Island tourism are in line with the research conducted by Ferdinan et al [7] which states that tourism development funds are not too large because the tourism sector is a secondary or preferred field, while the priority for regional government funding is health and education.

\subsection{Collaborative governance in the development of Lusi Island tourism during the New Normal period after the Covid-19 pandemic.}

Collaboration is the involvement of various actors including government, private sector, community, and academics in the implementation of public policies. To find out the condition of the collaboration of the stakeholders involved in the development of Lusi Island tourism, it can be seen from the initial conditions in building collaboration between the actors of Lusi Island tourism development, it was found that there were different strengths among the actors involved so that it became an obstacle to the collaboration, especially when suddenly The Covid 19 pandemic has hit until the New Normal period, the presence of the government, which has been awaited to be part of the solution for tourism development, has not yet arrived, both at the regional and village levels. Likewise, the private sector as a fund-raising investor is not at all interested in making Lusi Island tourism the main tourist spot in attracting tourists both at local, regional, and international levels. Those who are committed to developing tourism in order to revive the economy of the village communities around Lusi Island tourism are people who are members of the Tourism
Awareness Group (POKDARWIS) and APPWS (Association of Sidoarjo Travel Companies). Differences in strength and authority between parties, both between the central government and local governments, as well as between the government and the community have an impact on weakening support and trust from both the investor and the community itself.

The issue of differences in authority becomes an obstacle for regional governments to take action for tourism development. This is in accordance with the opinion[1] stated that the imbalance of power between actors causes weak trust and therefore ineffective collaboration. It's the same with journals[7]which stated that the Regional Tourism Office wanted to develop a tourist attraction but was hindered by Perhutani's land ownership status. So it is with journals [2] which states that the collaboration cannot run optimally because there are overlapping interests among stakeholders.

The new normal period, the presence of the government in developing Lusi Island tourism is not only needed in developing tourism, more than that, how the government through related agencies conducts socialization to embedded awareness of a clean and healthy tourism culture to the community in order to prepare the New Normal to be implemented to tourists who will visit Lusi Island.

Facilitative leadership is a driving figure who initiates tourism activities on Lusi Island in the new normal era after the Covid-19 pandemic. The leadership figure that should be carried out by the central government or regional government and even the village government, is actually carried out by the tourism awareness group (POKDARWIS) and supported by the Sidoarjo Travel Company Association (APPWS), this condition results in the development of Lusi Island tourism less than optimal. The presence between parties, especially those who have adequate authority and resources, will be a driving figure in determining the smoothness of creating a balance between the roles of each actor so that the collaboration runs optimally. As the research conducted by [11] that when the balance of actors' roles is not shown proportionally in relationships and cooperation, collaboration is not well developed.

The institutional design required for collaboration in the development of tourism on the island of Lusi, consisting of government and nongovernment agencies, such as; The Youth, Sports and Tourism Service, Maritime Affairs and Fisheries Service, Health Service, Kedungpandan Village Government, community (POKDARWIS), Sidoarjo Travel Company Association (APPWS), 
as well as academics, have not been formed, this is evidenced by the absence of an MOU as a legal basis for formation committed to the development of Lusi island tourism. Because there is no institutional design, automatically the actors involved do not have clear legitimacy and there is also no role and function of each actor so that collaboration between actors has not yet occurred.This finding is very far from expectations as the collaboration theory presented by [1] which states that clear ground rules must be applied consistently to convince actors that the collaborative process is fair, equitable and open.Likewise the research results [3] explained that consistent rules are needed for institutional design arrangements because they will affect a lack of trust and insecurity and thus have a negative impact on long- term planning. The same opinion was also conveyed [15] from the results of his research which states that the negative impact of the unclear job description of the actors because there is no formal agreement that is mutually agreed upon will result in low willingness and sharing of abilities and potentials of actors in carrying out collaboration. Therefore, the existence of the MOU is very important to regulate the rights, obligations and responsibilities of each actor.

The collaboration process takes place in meetings, trust, sharing of understanding, commitment, between POKDARWIS and APPWS only, done through online media (via WhatsApp, telephone or video call). With a less intense collaborative process between POKDARWIS \& APPWS, but enthusiasm in the form of commitment to revive Lusi Island as a healthy and safe and covid-free tourist destination continues until Lusi Island tourism is reopened in the new normal era. In line with opinion[1] stated that faceto-face dialogue is the heart of the collaborative process that can influence trust, mutual understanding, and commitment to collaboration. Importance The intensity of the meeting needed in the collaborative process in forming trust was also conveyed by 13] in the results of his research that the obstacle in the collaboration process is bringing all stakeholders together at one time so that it is difficult to reach an agreement, ultimately the level of trust tends to be low.

Based on the description of the stages of collaboration carried out in the development of Lusi Island tourism, the results of collaboration between stakeholders indicate the absence of government, private support, and the absence of optimal academics in developing Lusi Island as a tourist destination that is safe, comfortable and guarantees that Warp Island is free from Covid-19 Collaboration occurs only between POKDARWIS and APPWS.

\section{CONCLUSION}

Based on the results of the analysis presented related to Collaborative Governance in the Development of Lusi Island Sidoarjo in the New Normal Era, it can be concluded as follows:

1. The impact of the Covid-19 Pandemic on the socioeconomic conditions of the community around Lusi Island has changed quite significantly, the community's economy needs to be restructured, where people have to start new jobs after losing their jobs either because the workplace is closed or because of layoffs. While social interactions have also changed, during the pandemic, there were several communities exposed to Covid-19, this condition made local people aware to always maintain cleanliness and obey the rules according to the Health protocol.

2. Collaborative governance in the development of Lusi Island tourism during the New Normal period has not materialized as expected, the coordination that occurs between the government itself is unclear, where the regional government does not dare to take any action to prioritize the development of Lusi Island tourism, because legally, the tourism sector is entrusted to the Ministry of Maritime Affairs. (Central government). This condition causes a low level of investor confidence. Besides that, the presence of academics in various studies has not been carried out optimally, so that no mapping of the problem has been found as a contribution to the development of Lusi Island tourism. However, the enthusiasm of the community who joined the tourism awareness group (POKDARWIS) and APPWS became a Based-line in building collaboration to plant a dream and hope for the progress of Kedungpandan Village through the development of Lusi Island tourism. Although the interaction between POKDARWIS and APPWS is still carried out through online media in the form of Whatsapp and telephone or video call.

\section{ACKNOWLEDGMENT}

Thank you to the Kedungpandan Village Government, the Sidoarjo Travel Company Association (APPWS), and the Kedungpandan Tourism Awareness Group (Pokdarwis) for taking their time to share information and data. This research is supported by: Muhammadiyah University Sidoarjo, 
which supports both morale and material aspects in the implementation of research.

\section{REFERENCES}

[1] Ansell, C., \& Gash, A. (2007). Collaborative Governance in Theory and Practice. 543-571. https://doi.org/10.1093/jopart/mum032

[2] Arianti, D., \& Satlita, L. (2018). Collaborative Governance Dalam Pengembangan Konservasi Mangrove Baros di Desa Tirtohargo Kecamatan Kretek Kabupaten Bantul. Jurnal Natapraja, 7(1), 2406-9515. Retrieved from https://journal.uny.ac.id/index.php/natapraja

[3] Bichler, B. F., \& Losch, M. (2019). Collaborative Governance in Tourism: Empirical Insights into a Communitysustainability Collaborative Governance in Tourism : Empirical Insights into a CommunityOriented Destination. (November). https://doi.org/10.3390/su11236673

[4] Dinas Kepemudaan Olahraga dan Pariwisata Kabupaten. (2019). Data Kunjungan Wisata. Retrieved from Dinas Kepemudaan Olahraga dan Pariwisata Kabupaten website: https://disporapar.sidoarjokab.go.id

[5] Dinas Kepemudaan Olahraga dan Pariwisata Kabupaten Sidoarjo. (2018). KKP Kelola Pulau Lusi sebagai Destinasi Wisata Baru di Sidoarjo. Retrieved July 5, 2019, from Dinas Kepemudaan Olahraga dan Pariwisata Kabupaten Sidoarjo website:

http://disporabudpar.sidoarjokab.go.id/berita/det ail/kkp-kelola-pulau-lusi-sebagai-destinasiwisata-baru-di-sidoarjo

[6] Dinas Kesehatan Kabupaten Sidoarjo. (2020). Peta Sebaran Kasus. Retrieved from Dinas Kesehatan Kabupaten Sidoarjo website: http://covid19.sidoarjokab.go.id

[7] Ferdinan, Y., Makmur, M., \& Ribawanto, H. (2015). Pengembangan Wisata Alam Berbasis Ekowisatadalam Perspektif Pelayanan Publik (Studi pada Disparbud Kabupaten Nganjuk). 3(12), 2123-2127.Retrieved from http://administrasipublik.studentjournal.ub.ac.id/i ndex.php/jap/article/view/1106/445

[8] Kementerian Kelautan dan Perikanan. (2018). Pulau Lusi Butuh Sentuhan Serius Untuk Menjadi Menawan dan Menarik sebagai Destinasi

[9] Kepala Dinas Kepemudaan Olahraga dan Pariwisata Kabupaten Sidoarjo. (2019). Surat Keputusan Kepala Dinas Kepemudaan Olahraga dan Pariwisata Kabupaten Sidoarjo tentang Pengukuhan Pokdarwis Tlocor.

[10] Miles, B., \& Huberman, A. M. (1992). Analisis Data Kualitatif: Buku Sumber C Tentang Metode-Metode Baru. Jakarta: UI-Press.

[11] Ode, L., Islamy, S., Haning, M. T., \& Allorante, A. I. (2017). The Model Of Collaborative Governance In Tourism. 5(2), 1-12. Retrieved from https://www.idpublications.org/wpcontent/uploads/2017/03/Full-Paper-The-ModelOf-Collaborative-Governance-In-Tourismdevelopment-At-Buton-District.pdf

[12] Pemerintah Republik Indonesia. (2009). UndangUndang Republik Indonesia Nomor 10 Tahun 2009 tentang Kepariwisataan. Retrieved from https://jdih.kemenkeu.go.id/fullText/2009/10TAHUN 2009UU.HTM

[13] Robertson, P. J. (2011). An Assessment of Collaborative Governance in a Network for Sustainable Tourism: The Case of RedeTuris An Assessment of Collaborative Governance in a Network for Sustainable Tourism: The Case of RedeTuris Peter J. Robertson School of Policy, Planning. (May). https://doi.org/10.1080/01900692.2010.550078

[14] Sugiyono, P. (2015). Metode Penelitian Kuantitatif, Kualitatif, RnD. Bandung: Alfabeta.

[15] Umar, A., Burhanuddin, \& Nasrulhaq. (2019). Kolaborasi Aktor dalam Pembangunan Pariwisata Hutan Mangrove Tongke-Tongke Kabupaten Sinjai, Sulawesi Selatan. MATRA PEMBARUAN Jurnal Inovasi Kebijakan, 57-66. https://doi.org/10.21787/mp.3.1.2019.57-66 